\title{
PENDAMPINGAN KEGIATAN PEMBELAJARAN SISWA DENGAN MEMANFAATKAN BARANG BEKAS UNTUK MENINGKATKAN MINAT DAN KREATIVITAS BELAJAR PADA MASA PANDEMI COVID-19
}

\author{
Riza Faishol $^{1)}$, Meliantina ${ }^{2)}$, Eka Ramiati $^{3)}$, \\ Ellyana Ilsan Eka Putri ${ }^{4)}$, Syu'adah Murni Rahayu ${ }^{5)}$ \\ Institut Agama Islam (IAI) Ibrahimy Genteng Banyuwangi, Indonesia \\ e-mail: riza@iaiibrahimy.ac.id, melivelvet@gmail.com, \\ numateraeka@gmail.com, ellyanaachmad@gmail.com, \\ rahayusani65@gmail.com
}

\begin{abstract}
Student learning assistance by utilizing secondhand goods aims to increase students' interest and creativity. This community service activity is carried out in several stages including: the preparation stage consisting of observation, interview to parents, delivery of strategies, and material bribery; the implementation stage consisting of socialization of the implementation of activities begins with the approach and mentoring of students; evaluation stage of the assessment of activities that have been carried out. The results of the activities that have been achieved are student learning assistance in preventing the transmission of corona virus, utilizing secondhand goods as a place to wash hands, utilization of used goods as handicrafts, and mentoring students in utilizing secondhand goods as a learning medium.
\end{abstract}

KEYWORDS: SecondHand Goods, Increased Interest in Learning and Creativity, Covid-19

\begin{tabular}{|c|c|c|}
\hline Accepted: & Reviewed: & Published: \\
December 02 2020 & January 07 2021 & February 15 2021 \\
\hline
\end{tabular}

\section{PENDAHULUAN}

Pandemi Covid-19 telah mengubah pola aktivitas masyarakat, termasuk dalam kegiatan belajar mengajar (KBM). Pemerintah memberlakukan pendidikan jarak jauh (PJJ) untuk mencegah semakin bertambahnya penularan virus di sekolah. Surat Edaran Menteri Pendidikan dan Kebudayaan (Mendikbud) Nadiem Anwar Makarim mengatakan, "Prinsip dikeluarkannya kebijakan pendidikan di masa Pandemi Covid-19 adalah dengan memprioritaskan kesehatan dan 
93 | Pendampingan Kegiatan Pembelajaran Siswa Dengan

Memanfaatkan Barang Bekas Untuk Meningkatkan Minat

Dan Kreativitas Belajar Pada Masa Pandemi Covid-19

keselamatan peserta didik, pendidik, tenaga kependidikan, keluarga, dan masyarakat". (www.kemdikbud.go.id)

Namun dalam implementasinya, terdapat permasalahan yang mengakibatkan tidak efektifnya kegiatan belajar mengajar, melalui wawancara yang penulis laksanakan di Dusun Petahunan, Rt 04/Rw 02 Desa Jajag, kepada orang tua siswa yang terdampak Covid-19 terdapat beberapa kendala dalam proses pemberlakuan belajar dari rumah, diantaranya:

1. Proses belajar mengajar yang digeser menjadi virtual selama pademi Covid-19 menjadi kurang menarik.

2. Kurangnya pengetahuan orang tua terhadap teknologi menjadikan siswa tersebut lebih sering menggunakan waktunya untuk bermain game daripada belajar.

3. Keterbatasan perangkat maupun kuota untuk mengakses internet.

Maka perlu adanya pendampingan belajar siswa guna meningkatkan minat dan kreativitas siswa, salah satunya dengan memanfaatkan barang-barang bekas. Menurut Purwadarminta (2000) dalam (Purwasasmita, 2010) pendampingan adalah suatu proses dalam menyertai dan menemani secara dekat, bersahabat dan bersaudara, serta hidup bersama-sama dalam suka dan duka, bahu membahu dalam menghadapi kehidupan dalam mencapai tujuan bersama yang diinginkan. Sedangkan media barang bekas merupakan alat yang digunakan dalam pembelajaran yang berasal dari segala sesuatu yang tertinggal atau sudah tidak digunakan lagi yang dapat digunakan menjadi barang yang baru yang lebih bernilai guna yang sering disebut dengan sampah. Penanggulangan sampah kini bukan hanya tanggung jawab pemerintah namun seluruh lapisan masyarakat tidak memandang profesi, sebagai langkah dalam penanggulangan sampah kini guru memanfaatkan sampah atau barang bekas di dunia pendidikan. (Arief, 2012:1). Sebagai bentuk kepedulian terhadap lingkungan, sikap peduli lingkungan dalam kehidupan bermasyarakat lebih kental diartikan sebagai reaksi peduli seseorang terhadap lingkungannya. Dengan sikap peduli lingkungan maka akan tercipta lingkungan yang bersih dan asri. (Tamara, 2016)

Pada pendampingan belajar memanfaatkan barang-barang bekas ini diharapkan dapat menjadikan siswa sadar diri untuk menjaga kebersihan diri sendiri dan tempat tinggal, siswa belajar untuk tidak membuang sampah sembarangan, menumbuhkan kreativitas dalam belajar siswa, memiliki bekal dan pengalaman baru dalam pembelajaran, memiliki kepedulian terhadap lingkungan, serta membantu melatih kemampuan berfikir dan penuangan ide-ide baru dalam pembelajaran. 
Riza Faishol, Imam Mashuri, Eka Ramiati, Idi Warsah \& Hikmah Nur Laili| 94

\section{METODE PELAKSANAAN} berikut:

Pelaksanaan kegiatan pengabdian ini dilakukan dengan cara sebagai

\section{a. Tahap Persiapan}

1. Dalam tahap persiapan, penulis melakukan observasi, wawancara terhadap orang tua siswa yang terdampak Covid-19 pada hari Kamis 11 Juni 2020.

2. Penyampaian strategi pendampingan yang akan dilakukan yaitu berupa kegiatan pemaanfaatan barang bekas.

3. Penyusunan materi dan kelengkapan peralatan untuk pelaksanaan kegiatan.

\section{b. Tahap Pelaksanaan}

1. Sosialisasi

Pelaksanaan kegiatan diawali pendekatan tehadap siswa melewati pengenalan media pembelajaran. Dengan mengedukasikan kepada siswa tersebut bahwa media pembelajaran yang akan digunakan sangat berperan penting terhadap diri sendiri dan lingkungan sekitar. Yakni perlunya memanfaatkan barang-barang bekas hasil daur ulang sebagai media pembelajaran yang menarik dan menyenangkan.

2. Pendampingan

Dalam pendampingan memanfaatkan barang bekas ini siswa diajarkan bagaimana cara membuat media pembelajaran tersebut. Kemudian siswa mempelajari media yang telah dibuat dan menulisnya di buku tulis sebagai hasil pembelajaran.

\section{c. Tahap Evaluasi}

Tahap evaluasi dilakukan untuk melihat tingkat keberhasilan kegiatan mulai dari awal, tahap pelaksanaan, hingga capaian hasil kegiatan. Partisipasi peserta didik dalam pelaksanaan program ditunjukkan dengan adanya dokumentasi saat pendampingan berlangsung. Evaluasi terhadap peserta pendampingan dilakukan setiap satu minggu sekali guna untuk mengetahui kekurangan dan solusi memperbaikinya kembali. 
95 | Pendampingan Kegiatan Pembelajaran Siswa Dengan

Memanfaatkan Barang Bekas Untuk Meningkatkan Minat

Dan Kreativitas Belajar Pada Masa Pandemi Covid-19

\section{HASIL DAN PEMBAHASAN}

\section{Pendampingan Belajar Siswa Dalam Mencegah Penularan Virus Corona dan Memanfaatkan Barang Bekas Sebagai Tempat Cuci Tangan}

Kegiatan yang pertama dilakukan adalah kegiatan bercerita yang bertujuan untuk melatih kemampuan mengingat dan melatih rasa percaya diri siswa. Dalam pelaksanaan pendampingan belajar ini, siswa diajarkan bagaimana pencegahan penularan virus Corona yaitu:

1. Mencuci tangan dengan air.

2. Makan-makanan bergizi dan matang.

3. Memakai masker bila berpergian dan sakit.

4. Menghindari tempat-tempat ramai atau memberikan jarak 1 meter.

Siswa juga belajar bagaimana mencuci tangan dengan baik dan benar dengan memanfaatkan barang bekas timba yang masih bisa dipergunakan kembali, menjadi tempat cuci tangan.

Ada 9 langkah yang siswa pelajari dalam mencuci tangan diantaranya: 1 . Membasahi tangan dengan air; 2. Menuangkan sabun pada tangan secukupnya untuk menutupi semua permukaan tangan; 3. Menggosokkan telapak tangan yang satu ke telapak tangan lainnya; 4. Menggosokkan punggung tangan dan sela jari; 5. Menggosokan punggung jari ke telapak tangan dengan posisi jari saling bertautan; 6. Genggam dan basuh ibu jari dengan posisi memutar; 7. Menggosokkan bagian ujung jari ke telapak tangan agar bagian kuku terkena sabun; 8. Menggosokkan tangan yang bersabun dengan air yang mengalir; 9. Mengeringkan tangan dengan lap sekali pakai.

Berdasarkan hasil dari pembelajaran tersebut siswa memiliki kesadaran untuk selalu menjaga kebersihan diri, dan tempat, siswa mematuhi peraturan yang diberlakukan yakni menggunakan masker, menjaga jarak, dan mencuci tangan sesudah berpergian atau menyentuh benda-benda luar, siswa menerapkan pola hidup sehat dengan makan-makanan bergizi dan seimbang. 
Riza Faishol, Imam Mashuri, Eka Ramiati, Idi Warsah \& Hikmah Nur Laili| 96

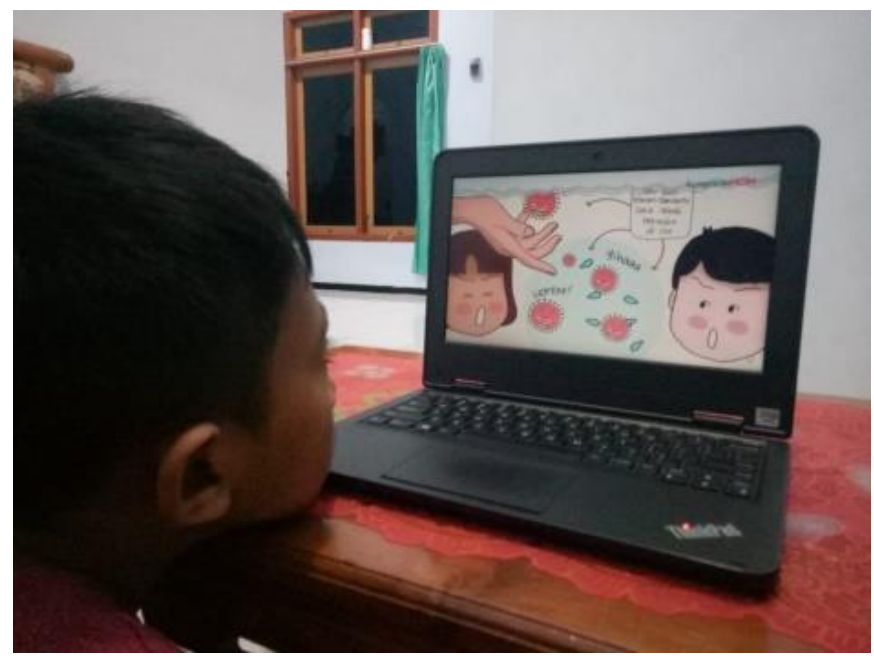

Gambar 1. Siswa belajar cara mencegah penularan virus corona.
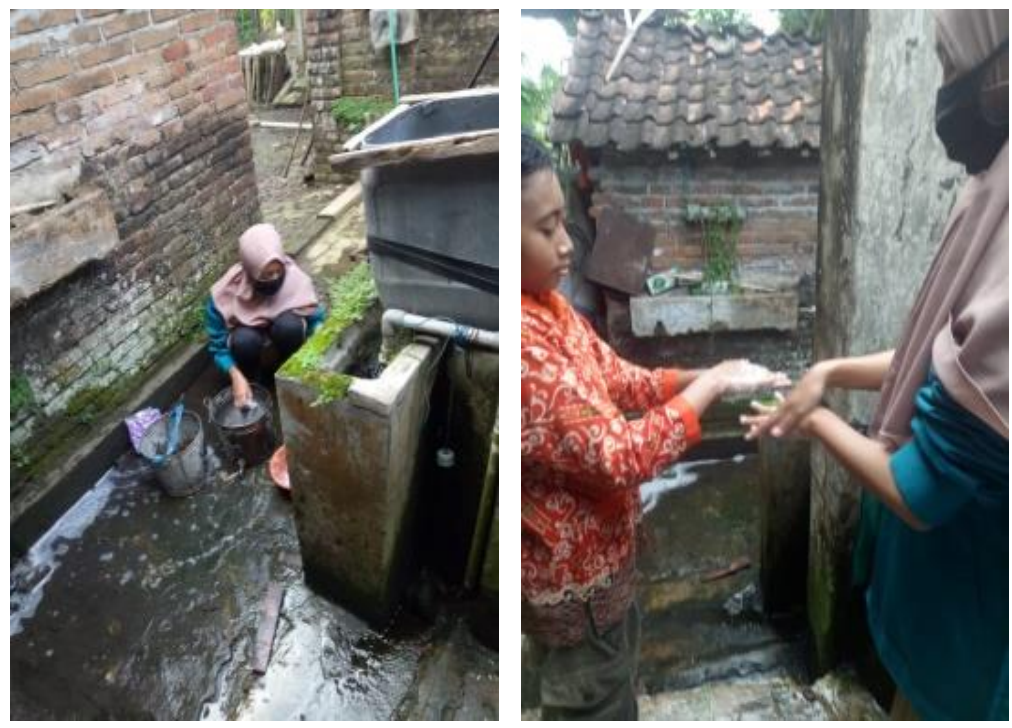

Gambar 2. Siswa memanfaatkan barang bekas timba dan belajar cara mencuci tangan dengan baik dan benar

\section{Pendampingan Siswa Dalam Memanfaatkan Barang-barang Bekas Sebagai Kerajinan Tangan}

Pelaksanaan pendampingan belajar siswa, pada pendampingan ini, siswa diajarkan untuk belajar kreatif memanfaatkan barang-barang bekas sebagai kerajinan tangan. Menurut (Nasional, 2008) kerajinan adalah barang yang dihasilkan melalui keterampilan tangan barang-barang sederhana, biasanya 
97 | Pendampingan Kegiatan Pembelajaran Siswa Dengan Memanfaatkan Barang Bekas Untuk Meningkatkan Minat Dan Kreativitas Belajar Pada Masa Pandemi Covid-19

mengandung unsur seni dapat pula didefinisikan sebagai usaha kecil-kecilan yang dikerjakan di rumah. Dengan memanfaatkan kertas bekas, tempat minum bekas, dan kaleng bekas, siswa mampu membuat tempat-tempat serba guna yang mampu di perjual belikan jika kemampuannya diasah terus menerus. Pemanfaatan tersebut menjadikan siswa pandai dalam menghemat uang, melatih kemampuan motorik siswa, mengajarkan siswa untuk mengikuti instruksi, melatih kesabaran, dan membangun rasa percaya diri siswa.
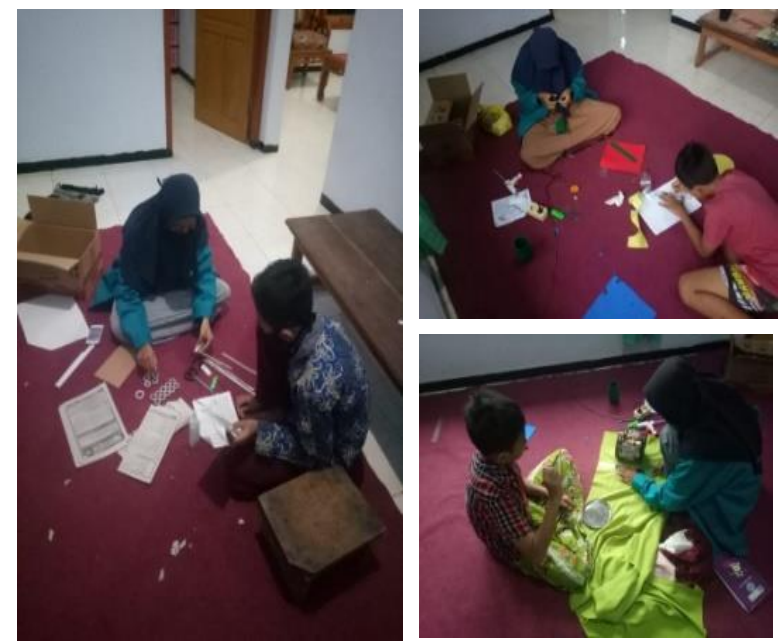

Gambar 3. Siswa belajar memanfaatkan barang-barang bekas sebagai kerajinan tangan.
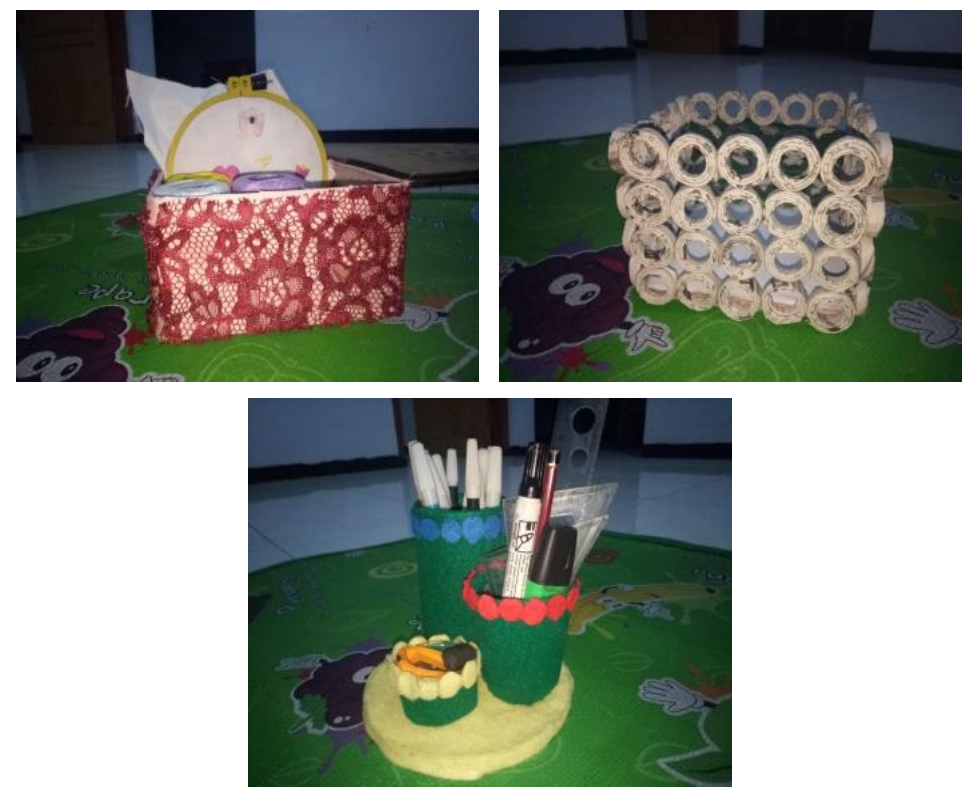

Gambar 4. Hasil dari pembelajaran. 


\section{Pendampingan Siswa Dalam Memanfaatkan Barang-barang Bekas Sebagai Media Pembelajaran}

Agar siswa lebih mudah dalam memahami dan tertarik dalam pelaksanaan pendampingan belajar, maka siswa diajarkan untuk memanfaatkan barang-barang bekas sebagai media pembelajaran. (Gagné, 2013) mengartikan media sebagai berbagai jenis komponen dalam lingkungan siswa yang dapat merangsang siswa untuk belajar. Sedangkan (Heinich et al., 1989) menyatakan bahwa: "Media adalah saluran komunikasi termasuk film, televisi, diagram, materi tercetak, komputer, dan instruktur". Media pembelajaran adalah segala sesuatu yang dapat digunakan untuk menyalurkan pesan dari pengirim ke penerima sehingga dapat merangsang pikiran, perasaan, perhatian dan minat serta perhatian siswa sedemikian rupa sehingga proses belajar terjadi (Arief, 2009). Dari beberapa pengertian di atas dapat disimpulkan bahwa media pembelajaran merupakan segala sumberdaya yang dapat digunakan untuk menyampaikan pesan pembelajaran dan dapat merangsang membangkitkan semangat dan kemauan siswa untuk belajar.

Diantaranya media yang telah siswa buat yaitu pemanfaatan kertas bekas sebagai media belajar tata surya, Tata surya dalam bahasa inggris disebut solar system terdiri dari sebuah bintang yang disebut matahari dan semua objek yang mengelilinginya. Pengertian tata surya yang lain adalah kumpulan benda-benda langit dimana matahari sebagai pusatnya. pada tahap awal, siswa belajar tentang pengertian dan macam-macam tata surya melalui video audio visual, siswa mencatat hal-hal yang telah dipelajari sebagai hasil pembelajaran.

Selanjutnya siswa membuat tata surya dari kertas bekas dengan langkahlangkah sebagai berikut: 1. Menyiapkan alat-alat yang akan di pergunakan seperti kertas bekas, lem, air, cat warna, dan kertas pelangi (hitam), 2. Langkah pertama, melarutkan kertas bekas ke dalam air sampai menjadi bubur kertas, 3. Langkah kedua membentuk kertas bubur menjadi bulatan-bulatan menyerupai planet, 4 . Langkah ketiga, mengeringkan bola-bola planet dengan bantuan matahari, 5 . Langkah keempat, memberikan warna sesuai dengan warna planet, 6. Langkah terahir, menempelkan bola-bola planet pada kertas pelangi sesuai dengan orbit lintasan dan susunan letak planet, agar planet tersebut mudah diingat siswa memberikan nama-nama planet di samping bola-bola planet tersebut.

Selain sebagai peningkatan minat belajar dan menumbuhkan kreativitas siswa, media ini menjadikan siswa mengetahui nama-nama planet dari urutan terdekat dari Matahari hingga terjauh dari Matahari, dari planet terkecil hingga 
99 | Pendampingan Kegiatan Pembelajaran Siswa Dengan Memanfaatkan Barang Bekas Untuk Meningkatkan Minat Dan Kreativitas Belajar Pada Masa Pandemi Covid-19

planet terbesar, mengetahui perbedaan suhu antar planet, mengetahui perbedaan Rotasi dan Revolusi, dan siswa mengetahui kebesaran ciptaan Allah SWT.

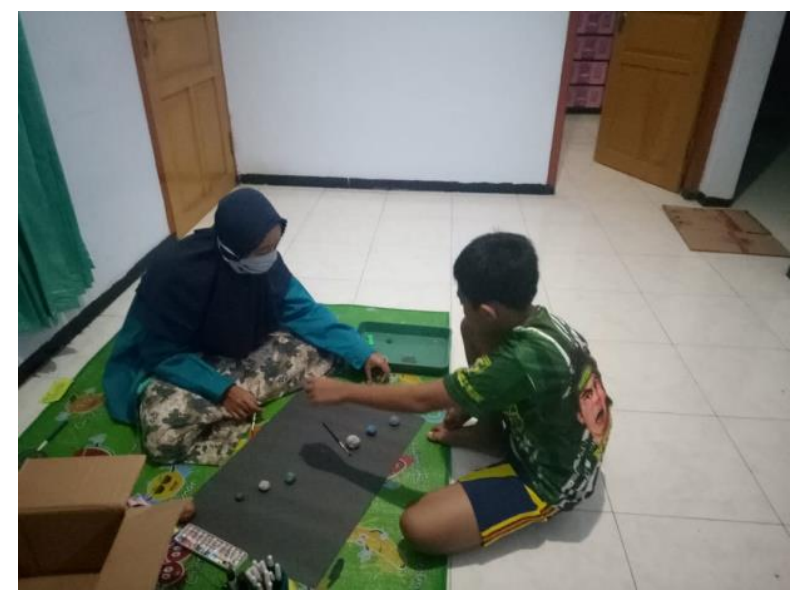

Gambar 5. Pendampingan siswa dalam memanfaatkan barang bekas sebagai media pembelajaran.

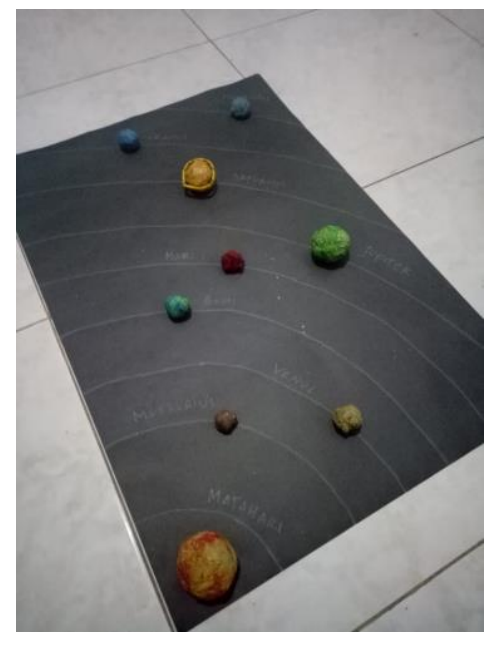

Gambar 6. Hasil dari pemanfaatan barang bekas sebagai media pembelajaran.

\section{SIMPULAN}

Berdasarkan kegiatan "Pendampingan Kegiatan Pembelajaran Siswa Dengan Memanfaatkan Barang Bekas Untuk Meningkatkan Minat dan Kreativitas Belajar Pada Masa Pandemi Covid-19" di Dusun Petahunan RT 
Riza Faishol, Imam Mashuri, Eka Ramiati, Idi Warsah \& Hikmah Nur Laili | 100

04/RW 02, Desa Jajag Kecamatan Gambiran pada tanggal 15 Juni-26 Juli 2020 yang telah dilaksanakan, dapat ditarik kesimpulan sebagai berikut:

1. Siswa mampu menerapkan protokol kesehatan guna mencegah penularan virus Corona.

2. Meningkatnya minat dan kreaktifitas siswa dengan memanfaatkan barangbarang bekas.

3. Siswa memiliki bekal pengetahuan dan pengalaman baru dalam pendampingan pembelajaran yang telah dilaksanakan.

4. Siswa memiliki kepedulian terhadap lingkungan dengan memanfaatkan barang-barang bekas yang bisa di daur ulang.

\section{DAFTAR RUJUKAN}

Arief, S. (2009). Media pendidikan, pengertian, pengembangan, dan pemanfaatannya. Jakarta: PT. Rajagrafindo Persada.

Gagné, R. M. (2013). Instructional technology: foundations. Routledge.

Heinich, R., Molenda, M., \& Russell, J. D. (1989). Instructional media and the new technologies of instruction. Macmillan.

Nasional, D. P. (2008). Kamus besar bahasa Indonesia pusat bahasa. Jakarta: PT Gramedia Pustaka Utama.

Purwasasmita, M. (2010). Strategi Pendampingan Daum Peningkatan Kemandirian Beujar Masyarakat. Jurnal Administrasi Pendidikan, 12(2).

Tamara, R. M. (2016). Peranan lingkungan sosial terhadap pembentukan sikap peduli lingkungan peserta didik di SMA Negeri Kabupaten Cianjur. Jurnal Geografi Gea, 16(1), 44-55. 